\title{
Et samfund af stumme
}

\section{Jan Jakob Floryan}

\section{'Hviskerne' er beretningen om de tragiske men- neskeskæbner under Stalin}

Orlando Figes: Hviskerne. Forlaget Sohn, Rødovre 2010, 800 sider + 60 sider noter.

Den vante fremstilling af Stalin-tiden er at tage fat i dens grusomhed og umenneskelighed og underbygge det med hårrejsende statistikker over forviste og myrdede. Det hører med at fremstille og analysere ondskabens mekanismer: Sikkerhedsapparatet, kommunistpartiet og magthavernes vilkårlighed i al almindelighed. Stor opmærksomhed vies styrkeforholdene inden for den inderste kreds om Stalin og hans hyppige afskedigelser af de nærmeste medarbejdere med alvorlige eller ligefremt fatale følger for dem. Denne 'ledelse ved terror' forplantede sig hele vejen ned fra politbureauet i top til den mest gudsforsagte kolkhos nederst.

Orlando Figes' indsats er at vise og dokumentere, hvad terroren betød for borgernes i deres hverdag. Der er afsnit, hvor han sætter den overordnede politiske ramme, og det er i sig selv spændende læsning, især da han udfordrer de gængse forestillinger $\mathrm{fx}$ om Stalins syn på $\mathrm{og}$ forventning om en kommende storkrig. Hovedvægten ligger imidlertid på enkeltskæbner, og dem er der omkring 500 af. Så mange personer står opført i navneregistret, og nogle nævnes kun en enkelt gang, andre som forfatteren Aleksandr Simonov adskillige gange.

Fælles er den minutiøse redegørelse for, hvad der overgik de enkelte og deres familier, eller hvordan de med større eller mindre succes søgte at undslippe terroren. De fleste skæbner er tragiske, og det gælder børn som voksne eller gamle. Figes har, bistået af en gruppe researchere, indsamlet et imponerende materiale og bygger på alt fra officielle dokumenter og avisartikler til private dagbøger, litterære fremstillinger, privatpersoners arkiver og ikke mindst den mundtlige fortælling. Det er overlevende ofre, der taler, eller nok så ofte deres efterkommere eller overlevende pårørende. 


\section{Ofrene}

Det var millioner, der forsvandt ved et nakkeskud i sikkerhedspolitiet NKVD's kældre eller gik til grunde i den sibiriske kulde i Gulag-lejrene. Arrestationerne toppede i 1937-38, da omkring en sjettedel af befolkning var i tvangslejre.

I det tempo kunne det ikke fortsætte, måtte Stalin konkludere, for skønt tvangsarbejderne blev udbyttet maksimalt økonomisk, kunne sovjetsamfundet ikke klare denne byrde. Derfor blev den sadistiske dværg Nikolaj Jezjov afsat som NKVD-chef og skudt. Efterfølgeren Genrikh Jagoda, der blandt andet blev berygtet for sine voldtægter af kvindelige fanger og af andre kvinder, han fik i sin magt, fik heller ikke lang tid i embedet. Også han blev skudt. Efterfølgeren Lavrentij Berija fik til opgave at 'civilisere' terrorsamfundet og overlevede Stalin for blot at blive summarisk henrettet af sammensvorne marskaller som led i opgøret med Stalins system efter dennes død.

Det var ikke mindre farligt at være i toppen end i det øvrige samfund. En stor del af de ofre, Figes fører frem, var medlemmer af partiet eller dets ungdomsorganisation Komsomol. Den typiske fremgangsmåde var, at en arrestant som noget af det første blev frataget partimedlemskabet. Derefter fulgte arbejdet. Den tilbageblevne familie blev sat ud af lejligheden og måtte hutle sig igen- nem i bedste fald hos familie, i værste i kældre eller på banegårde. At tage til provinsen og finde sig en faldefærdig rønne var også en mulighed, men det efterlod spørgsmålet om, hvad man skulle leve af.

Børnene blev ofte smidt ud af skolen og hvis ikke, stærkt forfulgt af lærere og kammerater som 'folkefjender'. Det var den stående anklage, der kunne passe på alle. Variationerne hed 'fjende af socialismen', hvis man var intellektuel, 'klassefjende', hvis man stammede fra adelen, borgerskabet eller gejstligheden, eller 'kulak', hvis man var en driftig bonde måske med lidt mere jord end gennemsnittet og to køer og totre grise.

Kulakkerne udgjorde hovedparten af de fængslede, forviste og myrdede. Sovjetunionen var et bondesamfund, og sovjetmagten havde i første omfang fået bønderne over på sin side ved at love dem jord. Den fik de og fik lov til at beholde til begyndelsen af 1930'erne. Så satte kollektiviseringen ind. Bønderne strittede imod, men blev knægtet enten af udsendte brigader af bevæbnede ungkommunister eller ved storstilede operationer foretaget af sikkerhedspolitiet og hæren, hvor man slet og ret slog en ring om millioner af mennesker, konfiskerede alt deres forråd, hindrede enhver trafik af fødevarer ind i kredsen og ventede på, at de skulle dø af sult. I dag mindes ukrainere som officiel sørgedag holdomor, sultedøden. 


\section{LITTERATUR}

Ukraine havde været en af verdens største kornproducenter i konkurrence med USA, Canada og Argentina.

\section{Amoralsk diktatur}

To forhold kræver endnu fremhævelse. Det ene er angiveriet og det andet den ufattelige tro på kommunismen og sågar på Stalin også hos terrorens ofre. At angive sine arbejdskollegaer, chefer, naboer ja sågar familiemedlemmer var yderst udbredt og skete som regel anonymt. Angivelserne blev taget for gode varer af NKVD, ikke undersøgt, men dannede grundlag for sigtelse og domfældelse.

Det med domfældelse tog man let på. Da de ordinære domstole var for langsomme, indførtes særlige trojkaretter, hvor tre repræsentanter for NKVD, anklagemyndigheden og partiet afgjorde sagerne. Forsvarsadvokater var der ikke tale om. Her hed det sig i bedste fald 10 års Gulag, i værre tilfælde 25 år og allerværst 'ti år uden ret til korrespondance'. Det sidste var den løgn, de pårørende fik, når arrestanten blev skudt.

Angiveriet var usmageligt og moralsk forkasteligt, men fremmet af et i sig selv amoralsk diktatur. Særligt kvalmende er det at læse hos Figes om børnenes angiveri. Det kunne gælde deres kammerater, men også forældre. Skrækeksemplet er Pavlitjek (Lillepoul) Morozov. En ukrainsk knap tiårig dreng, der angav sin far for at have skjult noget korn under holdomor. Faren blev skudt, Lillepoul gjort til helt, som alle skolebørnene lærte om og gerne skulle have som forbillede. Han var dog en lille satan, og til sidst fik de øvrige beboere i kolkhosen nok af ham. Han kom voldsomt af dage.

Det andet ubegribelige træk, der går igen og igen i Figes' kortbiografier, er den kommunistiske tro. Selv på vej til dødscellen holdt mange kommunister fast ved deres overbevisning og forklarede sig selv deres skæbne med, at det tjente partiets vel. Alt kunne og skulle ofres på dets alter. I 1920'erne og 1930'erne gjaldt det også kærlighedslivet, der blev betragtet som uværdigt og forstyrrende i en kommunists liv.

Forholdet mellem mand og kvinde blev stærkt nedtonet fra officielt hold, for det havde rigtige kommunister ikke tid til. Familien blev udskreget som den borgerlige kulturs sidste bolværk og søgt afskaffet eller i alt fald presset mest muligt. Det betød at mange, ikke mindst børnene, førte et dobbeltliv: Et offentligt som loyale kommunister og et privat, hvor de dyrkede gamle familietraditioner eller sågar kristendom.

Det sidste skulle foregå i dybeste hemmelighed og blev ofte varetaget af bedstemødrene, som Figes udråber til de egentlige helte, for de søgte at føre familietraditionerne og det humane samfundssyn videre. I familierne talte man ikke om poli- 
tik, for hvad hvis ens kone eller mand var stikker? Børnene var den største fare, for de kunne nemt komme til at sige videre, hvad de havde hørt hjemme. Hvis voksne derfor overhovedet kom ind på farlige emner, foregik det hviskende.

\section{Fascinationen af Det Onde}

Der kommer talrige bogudgivelser om Stalin og Hitler, selvom der efterhånden er gået mere end et halvt århundrede, siden de huserede i verden. Det er biografier, analyser og forsøg på at forstå og forklare deres personlighed.

På flere punkter ligner de to forbrydere hinanden: De steg begge til magtens tinder fra usle kår og fra underklassen. De havde begge svært ved at klare sig, før de slog ind på deres politiske bane. Stalin lagde ud med at være rød terrorist og bankrøver, Hitler med at grundlægge sin egen bevægelse. Både Stalin og navnlig Hitler havde store oratoriske evner og kunne føre masserne med sig, om end Hitler gjorde det mere udpræget og bedre end Stalin.

De mestrede sammensværgelsernes kunst og besad evnen til at manipulere og udmanøvrere andre, som de opfattede som konkurrenter, for til sidst at skaffe sig af med dem. For Hitler var det opgøret med Ernst Röhm og SA, som han fandt for socialistisk og erstattede med det helt igennem nationalsocialistiske SS. Röhm blev henrettet. Stalin skil- te sig af med stort set alle fra inderkredsen omkring Lenin, som havde haft afgørende roller i det bolsjevikiske kup i 1917. Det gælder Trotskij, Bukharin, Radek og talrige andre tidligere revolutionsførere. Skueprocesser og henrettelser var midlet.

Vi fascineres af Det Onde og stirrer på disse to menneskegestalter (Mao Tse-dung, Pol Pot og andre kan føjes til rækken) og forfalder måske til at anse dem som alle ulykkernes ophavsmænd.

Det var de også, men de stod ikke alene, og Figes anskueliggør med al $ø$ nskelig tydelighed, hvordan den stalinistiske maskine fungerede nærmest af sig selv, når først 'Fædrelandets geniale leder og største søn' havde sat den i bevægelse. Der var millioner i partiet, hundredtusinder i NKVD, blandt andet til at bevogte lejrene og sørge for tvangsarbejdet, og igen millioner af stikkere. Stalinismen som levevis og model inficerede samfundet helt ind i privatsfæren.

\section{De 'ødelagte biografier'}

Den fik også mennesker til at ændre på sig selv og i alt fald på deres biografier. Hundredtusinder havde 'ødelagte biografier', dvs. at de stammede fra samfundsskadelige klasser. Det gjaldt selvsagt adelen, der blev udraderet som samfundsgruppe, selv om enkelte formåede kun at overleve ved at fornægte deres slægt, afstamning og identitet. Intellektuelle der rutinemæssigt 


\section{LITTERATUR}

blev stemplet som liberalister og borgerlige demokrater, måtte også reparere på deres biografier for at skjule herkomsten. Gejstlige havde ikke en chance, men prøvede at give sig ud for bønder.

Kulakkerne havde det ligeledes meget svært og måtte ty til mange løgne og tricks for at vinkle biografierne i overensstemmelse med systemets krav. Men det var svært, for i landsbyerne kendte alle hinanden, og der var altid mindst én, der kunne afsløre den sande identitet for myndighederne. At blive arresteret og måske løsladt efter nogle år betød også en ødelagt biografi. Det strakte sig videre og omfattede hele familien.

Som hustru til en arresteret mand blev kvindens biografi også ødelagt. Det gjaldt endvidere søskende og andre slægtninge. Værst gik det ud over børnene, der pludselig blev udstødt af ungdomsbevægelsen Pionererne eller den kommunistiske ungdomsorganisation Komsomol. De mistede deres venner, kammeraterne blev til fjender og lærerne til nådesløse vogtere.

En mulig løsning var at lade sig skille hurtigst muligt fra en arresteret mand eller kone. Børnene kunne afsværge deres far, mor eller begge forældrene og måske redde sig på denne vis. Man kunne rejse langt væk i det uendelige land, skifte navn og konstruere sig en ny biografi. Sikkerhed gav det imidlertid ikke, og man måtte leve i en evig angst og bæven for, at det skulle blive opdaget.

I det hele taget var sovjetsamfundet under Stalin gennemsyret af frygt. Det var meget få mennesker om nogen, man havde tillid til. Man kunne til enhver tid vente på at blive arresteret og mange sov med en pakket kuffert ved siden af sengen. Figes beretter om en datter, der kom sent hjem en aften og måtte ringe på, fordi hun havde glemt nøglen. Det tog lang tid før der blev åbnet, og så stod hendes far der fuldt påklædt og med kufferten i hånden. Han var hvid $\mathrm{i}$ ansigtet $\mathrm{og}$ havde sved på panden. Da det viste sig, at det var hende, og årsagen den glemte nøgle, gav han hende den første lussing i ansigtet nogensinde.

\section{Nazitysklands angreb}

Stalins udrensninger i militæret $\mathrm{i}$ 1937-38 førte til fjernelsen af de bedste generaler og oberster. Blandt dem helten fra Borgerkrigen og krigen mod Polen, marskal og viceforsvarskommissær M.N. Tukhatjevskij. Han blev dømt for landsforræderi og skudt. Talrige led samme skæbne, hvilket betød, at det sovjetiske forsvars øvre echeloner var alvorligt svækket, da Nazityskland angreb.

Figes beskriver medrivende, hvad der skete, da de tyske panserkolonner drev østover. Først og fremmest flygtede partibosserne og NKVD-folkene. Jøderne var også hurtige til at tage af sted, og netop Hviderusland 
og Ukraine husede de fleste af dem. De nærede ingen illusioner om nazisternes hensigter. Intellektuelle pakkede også kufferterne, mens bønderne blev, hvor de var. En del af dem troede endog (fejlagtigt) på, at tyskerne ville opløse kolkhoserne og give jorden tilbage til ejerne.

I de baltiske republikker blev de tyske tropper i begyndelsen modtaget som befriere fra det kommunistiske åg. I Ukraine var de ligeledes velkommen blandt mange indbyggere. Hurtigt vendte billedet, og den nazistiske terror åbenbarede sig. Det var ikke, hvad man havde håbet på. Selvstyre endsige uafhængighed ville tyskerne slet ikke høre på. Det hindrede dog ikke i titusindvis af baltere og ukrainere i at melde sig under det rød-hvide hagekorsflag. Ligesom danskerne fra Frikorps Danmark blev de indrulleret i Waffen-SS, men blev også sat ind i de berygtede Einsatzkommandos, hvis opgave var at opspore og eliminere jøder bag de tyske linjer.

Angrebet den 22. juni 1941 kom som lyn fra en klar himmel, om end Figes mener, at Stalin var klar over, hvor det bar hen. Hans taktik var imidlertid at vente længst muligt og lade 'kapitalisterne', dvs. i første omgang Storbritannien og Tyskland, slå hinanden fordærvet. Sådan gik det ikke, og Stalin kom selv i skudlinjen, da Hitler beordrede hovedparten af de tyske stridskræfter, hen mod 200 divisioner, mod øst. Stalin skal være blevet lamslået og trak sig tilbage til sin datja, sommerresidens, uden for Moskva. Den afgørende tale til det chokerede folk blev holdt af udenrigsminister og politbureaumedlem Vjatjeslav Molotov.

Først på tredjedagen var Stalin kommet sig så meget, at han kunne holde en radiotale til nationen. Han talte, skriver Figes, i afgrænsede sætninger med lange pauser i mellem, som om han skulle overvinde sig selv til det. Hans vejrtrækning var meget hørlig. Som noget nyt talte han om 'mine brødre og søstre og mine venner' i stedet for de obligate 'kammerater'. Han opfordrede dem til at forene sig i 'kampen på liv og død'. Senere, i 1942, kom den berygtede Befaling 227 'Ikke et skridt tilbage.' Dem, der tog et skridt tilbage, selv hvis det var militært velbegrundet, ventede kun eksekutionspeletonen.

\section{Kølleslag mod regimet}

Angrebet slog benene væk under sovjetregimet, og den mest brutale terror blev stillet i bero. Samtidig skete der en forvandling med soldaterne og efterhånden også med folk i baglandet. De mistede angsten og begyndte at tale rent ud om systemet, de holdt op med at hviske. "De har bedraget os i årtier, og fortjener ikke bedre", er et af Figes' citater.

Samtidig kan han dog skrive om den enorme offervilje, der greb folk, ikke for at forsvare Stalin og hans uvæsen, men for Ruslands skyld. 


\section{LITTERATUR}

"Denne grænseløse offervilje var Sovjetunionens stærkeste våben”, hedder det i Hviskerne.

Krigen var som et kølleslag i hovedet på systemet, og dets virkning varede ved i de første efterkrigsår. For det første havde soldaterne i regnen af tyske granater og maskingeværprojektiler udviklet helt andre og ægte mellemmenneskelige relationer end dem, sovjetstyret havde søgt at påtvinge dem. For det andet kom de til Europa og kunne trods krigens ødelæggelse se, hvor stor kontrasten var i forhold til de armodige sovjetiske forhold. Mange af de sovjetiske soldater var rene bøller, der plyndrede og voldtog i de 'befriede' lande, men nok så mange begyndte at stille spørgsmålstegn ved deres sovjetiske lærdom.

Det var samme effekt som i 1814, da russiske officerer vendte hjem fra Paris efter sejren over Napoleon. De fik set et samfund hævet civilisatorisk himmelhøjt over det russiske selvherskerdømme. Opildnet af det forsøgte en gruppe yngre officerer, Dekabristerne, i 1825 et kup mod zaren. Det blev slået ned og officererne henrettet.

Denne lektie var ikke spildt på Stalin. Han følte ubehag og utryghed ved den ånd, der herskede i 1945, 1946 og delvis 1947. Det var som om partiet og NKVD begyndte at miste grebet. Derfor blev terrorregimentet genoptaget i 1947 til de fleste sovjetborgeres forundring og forfærdelse. For havde de ikke lige bevist at kunne og ville kæmpe til det yderste for landet?

Den ånd af glæde og siden skuffelse, som prægede sovjetsamfundet i de umiddelbare efterkrigsår, er mesterligt gengives af Figes ikke mindst i kraft af de tusinder af interviews, der også ligger til grund for bogen. Skruen blev strammet om end ikke så meget som i de forfærdeligste år 1937-38. Sovjetborgerne måtte trækkes med umennesket Stalin frem til hans død i 1953. Derefter var Sovjetunionen stadig et totalitært land med en undertrykt befolkning, men den vilkårlige masseterror var ophørt. Slutstenen i denne udvikling blev Mikhail Gorbatjovs Perestrojka og Glasnost. To processer, der løb løbsk for ham og til slut førte til Sovjetunionens kollaps.

Så langt op i tiden går Figes ikke. Han følger kun nogle af de omtalte familier op i 1990'erne for at se, hvad frihed har betydet for dem.

Bogen er vel oversat fra engelsk af Steen Sohn og skæmmes kun af få trykfejl.

Jan Jakob Floryan er cand. mag. $\mathcal{E}$ art. 